\title{
The Relationship of Indonesian Language Learning with the Environment
}

\author{
Tatik Sri Wahyuni/19016058 \\ tatiksriwahyuni150@gmail.com
}

Indonesian language learning can be related to the environment, the environment becomes one of the components that influence the learning process. This can be related to language. Language is a communication tool that humans can acquire from birth. Suardi (et al, 2019) said that the mastery of a language by a child begins with the acquisition of the first language which is often called the mother tongue. Dardjowidjojo (in Suardi et al, 2019) says that language acquisition is a language acquisition process that is carried out by children naturally when they learn their mother tongue. The acquisition of the first language is closely related to the social development of children and the formation of social identity. In line with that, Yogatama (in Suardi et al, 2019) says that learning the first language is one of the overall developments of children to become members of a society.

Sumarsono (in Halawa et al, 2019) says that politeness in speech is one aspect of language that can improve the emotional intelligence of speakers because in communication, speakers and speakers are not only required to convey the truth, but must remain committed to maintaining harmonious relationships. In line with that, Rina (in Halawa et al, 2019) said that the language used is full of orderly manners, courtesy, and contains high values of respect. Politeness is a habit regarding behavior that applies in society. In everyday life situations, a polite attitude can have a positive impact on social relations with the surrounding environment. Therefore, politeness in speech is closely related to behavioral habits in a society or a person.

Ramadhan et al, (2019) said that environmental education is important to increase students' attitudes and awareness of the environment. Environmental education can make students think critically and contextually. This critical and contextual way of thinking will later affect Indonesian language learning, so that environmental education and language learning are interrelated. Sukma (2005) said that the use of language is closely related to social relations between speakers who are in the midst of society. 
Sukma et al, (2017) say that literacy skills have a significant influence on student success in learning and daily life. Through good literacy skills, it will help students in understanding spoken, written, and visual texts. Indriyani et al, (2019) and Sukma et al, (2019) say that student literacy needs to be improved, especially literacy. Then, it is also necessary to know how the implementation of literacy has been carried out in schools. Putri and Syahrul (2019) said that in the learning process at school, teaching reading must receive serious attention from Indonesian language educators. Through teaching reading, educators direct their students to be able to understand the content of reading.

Dania et al, (2020) say that the learning process can be carried out with all efforts with teachers and students with the aim of sharing and processing information so that the knowledge provided is useful for students which is marked by changes in individual behavior that are more good. With that, the learning process can be achieved in accordance with the goals that have been set. In line with that, Sukma (2020) said that the cultivation of important characters was instilled since students were still in elementary school. Character planting can be done in the learning process at school. The large diversity of characters and habits of students at school who come from different family backgrounds is a big influence that causes bad things from bad children's characters.

In learning Indonesian, attitudes and motivation also influence learning. Attitudes and motivation also play an important role in student learning outcomes. Prayitno and Amti (in Zulhafizh et al, 2013) say that learning outcomes are a tool to reveal the extent to which students have achieved predetermined goals. With this learning result, which shows the need for guidance for students who are less successful. Sukma (2019) said that teachers should motivate students. Through this motivation, a teacher can create various learning experiences for students.

Based on the questionnaire that the author distributed about "The relationship between Indonesian language learning and the environment" to 5th semester students of Padang State University, 3rd semester students of IAIN Batusangkar, 5th semester students of Imam Bonjol UIN, 5th semester students of UPI YPTK Padang, and 5th semester students of Ekasakti University. Of the total 39 respondents who took part in filling out the questionnaire, 37 were more dominantly female, and 2 male respondents were with a percentage of $94.9 \%$ female, $5.1 \%$ 
male. The results of the data from the percentage of questionnaires that have been carried out through the google form can be seen as follows.

The first statement, "environment is one of the supports in the Indonesian language learning process, especially in writing short stories" $17.9 \%$ stated strongly agree, $82.1 \%$ agreed, $0 \%$ disagreed, and 0\% disagreed. The second statement, "learning Indonesian language can foster an attitude of caring for the environment" $23.1 \%$ strongly agree, $76.9 \%$ agree, $0 \%$ disagree, and $0 \%$ disagree. The third statement, "environment is very important in learning Indonesian" $28.2 \%$ strongly agree, $61.5 \%$ agree, $10.3 \%$ disagree, and $0 \%$ disagree. Fourth statement, "a person can observe an object in the environment to write a text" $20.5 \%$ strongly agree, $74,4 \%$ agreed, 5.1\% disagreed, and 0\% disagreed. The fifth statement, "in learning Indonesian, writing texts with environmental themes can develop students' mindsets" 35.9\% strongly agree, $64.1 \%$ agree, $0 \%$ disagree, and 0\% disagree. The sixth statement, "Indonesian language learning efforts can be taught to children at an early age by introducing environmental themes" $25.6 \%$ strongly agree, $71.8 \%$ agree, $2.6 \%$ disagree, and $0 \%$ disagree. The seventh statement, "writing poetry is an example of a text produced by students by observing the environment" $17.9 \%$ strongly agree, $69.2 \%$ agree, $12.8 \%$ disagree, and $0 \%$ disagree. The eighth statement, "Indonesian language learning prioritizes a conducive environment in the teaching and learning process" $23.1 \%$ strongly agree, $76.9 \%$ agree, $0 \%$ disagree, and $0 \%$ disagree. The ninth statement, "using environmental themes in Indonesian language learning can trigger students' interest in learning the language and can increase knowledge" 28.2\% stated strongly agree, $69.2 \%$ agreed, $2.6 \%$ disagreed, and 0\% stated do not agree. The tenth statement, "learning Indonesian related to the environment can make students active in environmentally friendly activities" $28.2 \%$ strongly agree, $71.8 \%$ agree, $0 \%$ disagree, and $0 \%$ disagree.

Based on the explanation above, it can be concluded that the environment is closely related to learning Indonesian. Because, through the environment students are more likely to be happy with environment-based learning, and can increase students' awareness of caring for the surrounding environment. 


\section{REFERENCES}

Suardi, Indah Permatasari, Syahrul Ramadhan, and Yasnur Asri. (2019). First Language Acquisition in Early Childhood. Journal of Obsession: Journal of Early Childhood Education, 3(1), 265-273.

Halawa, Noibe, Erizal Gani, and Syahrul Ramadhan. (2019). Indonesian Language Politeness in Prohibiting and Criticizing the Seven Ethnicities. Journal of Language, Literature, and Its Teaching Lingua XV (2) 195-205.

Sukma E, Ritawati M, and Rizky A. (2017). Literacy Media Development in Improving Reading and Writing Skill of Early Class Students in Elementary School Padang Utara Padang. Advances in Social Science, Education and Humanities Research, Vol 118.

Sukma, Elfia. (2005). Application of Communicative Approach in Learning Indonesian Language Structure in Elementary School. Diction, Vol.12 No.1.

Ramadhan S, Elfia Sukma, and Vivi Indriyani. (2019). Environmental Education and Disaster Mitigation Through Language Learning. IOP Conference Series: Earth and Environmental Science, 314.

Sukma E, and VP Azrianti. (2020). Instilling Positive Characters in Students Using Folker in the Macromedia Application. Advances in Social Science, Education and Humanities Research, Volume 485.

Zulhafizh, Atmazaki, and Syahrul R. (2013). Contribution of Students' Attitudes and Learning Motivation to Indonesian Language Learning Outcomes. Journal of Language, Literature and Learning Vol. 1 No. 2, 13-26.

Dania, Rama and Elfia Sukma. (2020). Improving the Integrated Thematic Learning Process Using the Think Pair Share Cooperative Learning Model in Elementary Schools. Journal of Education Tambusai Vol. 4 No. 3, 2624-2636.

Putri, Diana and Syahrul R. (2019). The Correlation of Reading Comprehension Skills and Writing Skills in Reports on Observation Results of Class VII Students of SMP Negeri 4 
Pariaman. Journal of Indonesian Language and Literature Education, 8(1), series A 6269.

Sukma E, Ritawaty Mahyuddin, and Ari Suriani. (2019). Literacy Reading Poetry Elementary School Teachers. Journal of Educational Innovation and Primary School Learning Vol.3 No.1, 65-73. 